\author{
JANUSZ BALICKI \\ University of Cardinal Stefan Wyszyński, Warsaw, Poland \\ (D) https://orcid.org/0000-0001-9145-5630
}

\title{
Islamophobia in Poland in the Context of the Migration Crisis in Europe
}

\begin{abstract}
The high level of fear of Islam in Poland arose in spite of the fact that Poland has very few Muslims, just $0.1 \%$ of the population. This phenomenon began to surface in 2004, after Poland's accession to the EU but grew considerably in 2015, during the socalled migration crisis in Europe. Public opinion polls indicate that it can be described by the term "Islamophobia", which is often used in the literature of social and political sciences. The aim of the article is to explain the reasons for such a high level of fear of Muslims in Poland and the negative attitude towards Islam, given that it is contrary to the teaching of the Catholic Church, with which Polish society mostly identifies. The article consists of three parts. Part one presents the reaction of the EU Member States to the migration crisis in Europe. The second part analyzes the position of the United Right (Pol. Zjednoczona Prawica) political coalition in Poland, towards immigrants and refugees from Muslim countries. Part three confronts the stands of the United Right in Poland and the position of the Catholic Church towards Islam.
\end{abstract}

Keywords: Islamophobia, migration crisis, refugees, populism, migration policy, EU, solidarity

\section{Introduction}

According to Adis Duderija and Halim Rane, in the present time, "Islamophobia has become a widely discussed concept with regard to Muslims in the West and has attracted considerable concern from governments both in the Muslim World and the West, as well as transnational organisations including the Organisation of Islamic Cooperation (OIC) and the United Nations (UN). The term emerged towards the end of the 
twentieth century meaning fear, prejudice, and discrimination in relation to Islam and Muslims. However, there is not a single, agreed-upon definition of Islamophobia. The concept has attracted a large amount of academic research, particularly with respect to the manifestations and impacts of Islamophobia. It has also attracted criticism from those who claim that the use of the term inhibits legitimate criticism of 'Islam'."'

The term Islamophobia is already well established in political science literature. Although it is often accused of lacking precision, it seems that the second part of the term (phobia), understood as 'persistent' and 'unreasonable fear' or reluctance, in this case in relation to Islam and its followers, makes it possible to express in one word what constitutes the essence of the phenomenon. Monika Bobako in her work: Islamofobia jako technologia władzy. Studium $z$ antropologii politycznej (Islamophobia as a technology of power. A study in political anthropology) distinguishes two types of Islamophobia as a technology of power. The first is termed "progressive Islamophobia," and the second is "conservative Islamophobia." The first uses the image of "Europe" as a synonym of secular modernity, individual autonomy and freedom, while its opposite is "Islamic world" understood as a domain of non-modern or anti-modern values, determined by religious tradition. "Conservative Islamophobia" is a kind of anti-Muslim xenophobia that expresses fear of Islam in connection with the threat to the Christian identity of Europe. ${ }^{2}$

On the subject of Islamophobia, several reports have already been prepared dealing with European countries but also referring to the situation in the USA. One of them is the Tenth OIC Observatory Report On Islamophobia October 2016-May 2017, stating that in the period from October 2016 to May 2017 there was an increase in the level of unjustified fear of Islam in some parts of the world, which was manifested in the perception of Islam as a serious social threat, as an ideology in which violence is inherent, whose followers tend to act to the detriment of members of other religions. According to the above Report, Islam is often portrayed in Europe, including Poland, as a "foreign," and a "bloodthirsty religion." The above stereotypes significantly affect negative feelings, fears, or hatred towards followers of Islam. They can also be a reason for discrimination against Muslims, which results in their exclusion from economic, social, and public life in some countries. In this context, the authors of the above Report stated that the level of Islamophobia, especially in Europe and the United States was strengthened mainly by four factors: the victory

${ }^{1}$ A. Duderija, H. Rane: Islam and Muslims in the West. Major Issues and Debates. Cham, Switzerland 2019, p. 183.

${ }_{2}$ M. Вовако: Islamofobia jako technologia władzy. Studium z antropologii politycznej. Kraków 2017, pp. 311-312. 
of Donald Trump, the problem of immigration, the increase of populism and the extreme right-wing parties in Europe. ${ }^{3}$

Daniel Pipes, a well-known American journalist, historian, and political commentator born after the Second World War into a family of Polish Jews, whose father was an adviser on Russia and Central and Eastern Europe to President Ronald Reagan, recently decided to visit Poland. Pipes' decision to visit came about after Mateusz Morawiecki became the prime minister and made the statement that he and his government wanted to change the European Union by "evangelizing" it again. Pipes was particularly interested in the uncompromising position of the Polish government regarding the reception of immigrants and refugees from Middle Eastern and North African Muslim countries. He explained that he wanted to understand why his ancestors' country differed so much in this regard from western Europe. ${ }^{4}$

His observation of political discourse prompted him to claim that Poles disagree as to whether the Law and Justice party (PiS) promotes anti-Muslim sentiment or merely uses it for political purposes. According to the opposition, Law and Justice won the election and was able to form the first single-party government since the fall of communism precisely because "the specter of violence and tensions associated with the presence of Muslims in Western Europe has been emphasized," and scared many Poles. In turn, PiS supporters believe that the continuous flow of information from western Europe on jihadist activities, sexual harassment of women, honour killings, girl circumcision, criminal activity, misuse of social benefits, and the threat to Europe's religious and cultural identity have caused grassroots pressure for the ruling party to adopt an antiimmigration and anti-Islamic position. "The tsunami caused by Chancellor Merkel in 2015-2016 with a million Muslims wandering through Europe, frightened Polish residents to such an extent that $75 \%$ of them refused to accept even the smallest group of immigrants from Muslim countries." 5

This article attempts to find the answer to the questions how does one explain the extremely high level of fear of Islam in Poland (with only $0.1 \%$ Muslims), compared to other countries in the European Union and United Kingdom, in which Muslims constitute, for example, in the United

3 Tenth OIC Observatory Report on Islamophobia, October 2016-May 2017, presented to the 44th Council of foreign ministers Abidjan, Republic of Cote d'Ivoire 10-11 July 2017, p. 6.

${ }^{4}$ D. PIPEs: “Poland's Muslim ban." Washington Times, 1.07.2018, https://www. washingtontimes.com/news/2018/jul/1/how-poland-responds-to-western-europes-illegalmig/ [access: 1.06.2020].

5 Ibidem. 
Kingdom $6.3 \%$ and in France $8.8 \%$ of the population? Why is the fear of immigrants from Muslim countries not diminishing despite the passage of time? How can one explain the incompatibility of views of the Polish "Catholic" society with the position of the Catholic Church towards Islam?

The article consists of three sections. The first presents the reactions of EU Member States to the migration crisis in Europe. The second presents the position of the Right in Poland towards immigrants and refugees from Muslim countries. The third section attempts to confront the position of the United Right (Zjednoczona Prawica) towards Islam with the position of the Catholic Church, the Second Vatican Council and Pope Francis, and looks for the reasons for the fear of Islam that exists in Poland. ${ }^{6}$

The article is based on the analysis of statements of leading politicians and selected members of Polish society regarding the issue of admitting immigrants from Muslim countries into Europe, but also their attitudes to Islam itself as a religion. The sources for the article consist of reports on Islamophobia, opinion polls, sociological and political science publications on the migrant crisis in Europe and the fear of Islam.

\section{The reaction of the EU Member States to the migration crisis in Europe}

In March 2011, a civil war broke out in Syria, part of the so-called Arab Spring, which among others removed the Tunisian President Zine El Abidine Ben Ali and Egyptian President Hosni Mubarak, and gave hope to the Syrians that they, too, could overthrow their dictator. The authoritarian system in the Syria of President Bashar al-Assad began during the reign of his father President Hafez al-Assad, who in 1982 cracked down on the Muslim Brotherhood, which resulted in up to 40,000 deaths. The conflict in Syria revealed the religious divisions existing therein. Most Syrians are Sunni Muslims, but the Syrian security institution has long been dominated by members of the Alawite sect of which Assad is a member. ${ }^{7}$

${ }^{6}$ The United Right is a political coalition in Polish Parliament, created by three conservative parties: Law and Justice (Prawo i Sprawiedliwość); Agreement (Porozumienie) and Solidary Poland (Solidarna Polska).

${ }^{7}$ News Middle East. Documentaries, Al Jazeera, 1.10.2017, http://www.aljazeera. com/news/2016/05/syria-civil-war-explained-160505084119966.html [access: 1.06.2020]. 
The immediate cause of the outbreak of the war was the bloody suppression of peaceful protests after the brutal torture of 15 boys (one of them died at only 13 years old) who were detained for painting graffiti supporting the Arab Spring. In response to this, in July 2011, deserters from the army announced the formation of a Free Syrian Army to overthrow the government. ${ }^{8}$

Syrian President Assad decided to use any measure at his disposal to fight the opposition. In August 2012, the United Nations accused him of committing war crimes, including the use of chemical weapons against his own citizens. Events in the country meant that Syrians were leaving their place of residence and fleeing abroad to escape the massive bombing and repression. Lebanon became the main target for Syrian refugees. About 1 million people went there, which amounted to a quarter of Lebanon's pre-crisis population. The Arab television station Al Jazeera reported in October 2017 that during seven years of conflict in Syria, more than 465,000 Syrians were killed, more than a million were injured, and more than 12 million - half of the pre-war population of the country - were displaced from their homes, including 3.5 million who left their homeland. ${ }^{9}$ A high percentage of the seriously injured were children, who often needed to have their limbs amputated.

As a result of the presented events, in the years 2015-2016, more than 1.3 million people (not exclusively from Syria) entered the European Union according to the UN refugee agenda, UNHCR, by crossing the Mediterranean and Aegean Sea. Thousands of refugees lost their lives drowning in the attempt. In 2015, as much as 1,257,000 applicants for international protection were registered. Among them were refugees from Syria $(334,800)$ but also Afghans $(183,000)$ and Iraqis $(127,000)$. In 2015 Germany admitted 890,000 people, more than any other EU country. ${ }^{10}$

The vast majority of asylum applications submitted in 2016 also took place as well in Germany $(722,300)$, which accounted for $60 \%$ of all applications for residence in the EU: Italy $(121,200 ; 10 \%$, France $(76,000$; $6 \%)$, Greece $(49,900 ; 4 \%)$, Austria $(39,900 ; 3 \%)$, and the United Kingdom $(38,300 ; 3 \%)$, which was then still an EU Member State. In 2016, the number of new people seeking shelter in the EU Member States decreased

8 Ibidem.

9 Ibidem.

10 S. TRINEs: "Europe. Lessons From Germany's Refugee Crisis: Integration, Costs, and Benefits." World Education News \& Reviews, 2.05.2017, https://wenr.wes.org/2017/05/ lessons-germanys-refugee-crisis-integration-costs-benefits [access: 1.06.2020]. 
only slightly by 4,300 people. ${ }^{11}$ What impact did the above events have on Europe? How did EU countries react to them? According to the European Commission, Greece and Italy were the most burdened countries in this respect. In May 2015, for the first time, the Commission requested the relocation of people requiring international protection within the European Union from countries most heavily "laden" to other EU countries. In September 2015, the Council adopted two legally binding decisions establishing a temporary and exceptional relocation mechanism from Greece and Italy for 160,000 applicants. At the same time, the Commission recommended the implementation of an EU resettlement programme of 20,000 people. In July 2015, Member States and the countries applying the Dublin Regulation agreed to resettle 22,504 people from the Middle East and North Africa over a two-year period. However, relocations in 2016 were symbolic, resulting from various factors, including the lack of political will in Member States. ${ }^{12}$

The argument for refusing to show solidarity with encumbered countries was usually the arrival of immigrants and refugees from Muslim countries and the danger of terrorist attacks. In March 2016, far-right and populist parties in Slovakia won the parliamentary elections, and Prime Minister Robert Fico warned of the danger of Muslims in the election campaign. In May, Fico gave an interview in which he said that there is no place for Islam in Slovakia. In November, its government officially presented the EU with a plan that would enforce the protection of external borders or use the deportation of existing immigrants instead of requiring their relocation. Slovakia emphasized the need to introduce the principle of voluntary relocation and, like the remaining countries of the Visegrad Group (Czech Republic, Hungary, Poland), refused to accept refugees and immigrants who arrived via Italy and Greece. In December 2016, the Slovak government approved a law that would make it difficult to recognize Islam as a legal religion. The required number of followers, for any religion to be recognized was increased to $50,000 .{ }^{13}$

Thus, the massive population movements, especially from the Middle East and North Africa, unheard of since the Second World War, increased

11 Eurostat 46/2017, 16.03.2017, https:/ec.europa.eu/eurostat/documents/ 2995521/7921609/3-16032017-BP-EN.pdf/e5fa98bb-5d9d-4297-9168-d07c67d1c9e1 [access: 1.06.2020].

${ }^{12}$ Komisja EuropejsKa: Komunikat Komisji do Parlamentu Europejskiego, Rady Europejskiej i Rady. Pierwsze sprawozdanie $w$ sprawie relokacji i przesiedlenia. Bruksela, 16.3.2016, COM (2016) 165 final.

${ }^{13}$ Tenth OIC Observatory Report on Islamophobia, October 2016-May 2017, presented to the $44^{\text {th }}$ Council of foreign ministers Abidjan, Republic of Cote d'Ivoire $10-11$ July 2017, p. 45. 
support for conservative populist parties, especially in Central and Eastern Europe. Regarding Hungary, Paul Lendvai wrote: "Between June and September 2015 Fidesz poll ratings rose by the equivalent of 300,000 votes and Viktor Orban's popularity ratings rose from 43 to $48 \%$. The developments in Hungary in 2015-2016 confirmed yet again the well-known maxim of the French psychologist Gustave Le Bon (1841-1931): 'People in masses are like children, easy to influence and even easier to steer if the message is well packaged and repeated often enough.' Opinion polls leave no doubt that Viktor Orban has once again succeeded in exploiting a single issue, in this case immigrants and refugees, to achieve a turnaround in his support." 14

In the summer of 2016 a representative poll conducted in ten European countries, by the American Pew Research Center, ascertained that the fear of a terrorist attack by refugees was strongest in Hungary: 76\% of those questioned agreed with this, compared with a statistical average of $59 \%$ for the ten polled countries (Poland 71\%). Even greater was the fear of refugees taking jobs at the expense of Hungarians: $82 \%$ of Hungarians were of this opinion as against an average of 50\% elsewhere (Poland $75 \%)$. Hungary also topped the list in the expression of anti-Muslim sentiment $72 \%$; Poland $66 \%$; UK $28 \% .{ }^{15}$

Controversy regarding the reception of people from other cultures occurs not only in Central and Eastern European countries. The Tenth OIC Observatory Report on Islamophobia reports that the Norwegian Minister of Integration, Sylvi Listhaug, wrote in a post: "I think those who come to Norway must adapt to our society. Here we eat pork, drink alcohol and show our face. You must comply with the values, laws and regulations that are in Norway when you come here." Such statements, however, met with a sharp response. For example, Omar Gilani Syed, a criminologist working to integrate refugees, asked if Sylvi Listhaug could continue to be responsible for integration if she makes such statements? In turn, Ms. Zaineb Al-Samarai, a politician from the Norwegian Labour Party accused Listhaug of deliberately seeking to separate Muslim immigrants from the rest of Norwegian society. She said: “I don't believe that Norwegian culture is weak, that it will decay and die if someone chooses to wear the hijab as their national costume. Norwegian culture, as you think, is not so weak or endangered. Norwegian culture is much more than pork and headgear." 16

14 P. Lendvai: Orbán. Europe's New Strongman. London 2017, p. 193.

15 Pew Research Center, Washington DC, 11 June 2016. The poll was conducted in the spring of 2016 in Hungary, Poland, the Netherlands, Germany, Italy, Sweden, Greece, the UK, France and Spain, Ibidem.

16 Tenth OIC Observatory Report on Islamophobia, October 2016-May 2017, presented to the 44th Council of foreign ministers Abidjan, Republic of Cote d'Ivoire 10-11 July 2017, p. 46. 
The size of Muslim communities in individual European Union countries varies greatly. Table 1 shows the estimated data for six countries containing the highest number and proportion of Muslims in relation to the entire population of the country.

Table 1. Estimated size of Muslim population in 2016 in European Countries

\begin{tabular}{|l|c|c|}
\hline \multicolumn{1}{|c|}{ Country } & $\mathrm{N}$ & $\%$ \\
\hline France & 5720000 & 8.8 \\
\hline Germany & 4950000 & 6.1 \\
\hline United Kingdom & 4130000 & 6.3 \\
\hline Italy & 2870000 & 4.8 \\
\hline Netherlands & 1210000 & 7.1 \\
\hline Spain & 1180000 & 2.6 \\
\hline
\end{tabular}

Source: Europe’s Growing Muslim Population, Pew Research Center, 29.11.2017.

According to Pew Research in 2016, France had the largest number of Muslims: 5.72 million, 8.8\%; Germany came second with 4.95 million, 6.1\%; in third place was the UK, where the number of Muslims reached about 4.13 million, which was $6.3 \%$ per cent of the population. In fourth place was Italy: 2.87 million, $4.8 \%$; in fifth place was the Netherlands: 1.2 million, with a percentage of $7.1 \%$; Spain came in sixth place with 1.18 million Muslims, which amounted to only $2.6 \%$ of their population.

Table 2. Unfavourable attitude towards Roma, Muslims, and Jews in Europe

\begin{tabular}{|l|c|c|c|}
\hline \multirow{2}{*}{ Country } & \multicolumn{3}{|c|}{ Unfavourable attitude [\%] towards } \\
\cline { 2 - 4 } & Roma & Muslims & Jews \\
\hline Italy & 82 & 69 & 24 \\
\hline Greece & 67 & 65 & 55 \\
\hline Hungary & 64 & 72 & 32 \\
\hline France & 61 & 29 & 10 \\
\hline Spain & 49 & 50 & 21 \\
\hline Poland & 47 & 66 & 24 \\
\hline UK & 45 & 28 & 7 \\
\hline Sweden & 42 & 35 & 5 \\
\hline Germany & 40 & 29 & 5 \\
\hline Netherlands & 37 & 35 & 4 \\
\hline
\end{tabular}

Source: Spring 2016, Global Attitudes Survey, Q36a-c, https://www.pewresearch.org/ global/2016/07/11/negative-views-of-minorities-refugees-common-in-eu/ [access: 1.06.2020]. 
Table 2 shows the "unfavourable" attitude towards Roma, Jews, and Muslims in selected European countries. It juxtaposes groups that are difficult to compare due to differences in the reasons for "reluctance" meted out against them. Nevertheless, it can be assumed that their common feature is being described by the term "foreign"/ "stranger".

Table 3. Unfavourable views of minority groups in East and West Germany (\%)

\begin{tabular}{|l|c|c|}
\hline Negative views against & East Germany & West Germany \\
\hline Roma & 48 & 34 \\
\hline Muslims & 36 & 22 \\
\hline Jews & 12 & 5 \\
\hline
\end{tabular}

Source: Spring 2019, Global Attitudes Survey, Q48a-d, p. 87, https://www.pewresearch.org/ global/2019/10/14/minority-groups/pg_10-15-19-europe-values-06-03/ [access: 1.06.2020].

Table 3 shows a clear difference in the attitude of the former East and West German societies towards minorities, which makes one wonder about the reasons for this. Similarly, Die Welt writes that in eastern parts of Germany, where few Muslims live, there were stronger reservations towards people following Islam. According to the Bertelsmann survey, $30 \%$ of people interviewed in the east said they did not want Muslims as their neighbours, compared to $16 \%$ who expressed the same preference in western German states. ${ }^{17}$ Are these differences between West and East Germany only due to East German society's lack of multicultural experience, or are there deeper reasons arising from the differences between Western and Central and Eastern Europe because of the different experiences of these societies after the Second World War?

Like their counterparts from the former East Germany, many Europeans from Central and Eastern Europe, who have had very limited experience of Islam (Poland $-0.1 \%$; Hungary $-0.4 \%$ of the population, respectively) believe that Muslims not only do not want to, but they cannot integrate, because it is something inside them that makes them different to us, Europeans (religion, culture, civilization etc.).

This type of opinion continues to shape society through the populist governments that consciously raise a fear of Islam for political purposes. In building such beliefs, populists have been helped by the tragic events in the Middle East, such as the war in Syria, the creation of a terrorist organization calling themselves the "Islamic State", invoking the concept of caliphate, which is very precious to Muslims around the world, and

17 "Germans support democracy, but are concerned about Islam." Die Welt, 11.07.2019, https://www.dw.com/en/germans-support-democracy-but-are-concernedabout-islam/a-49549541 [access: 1.06.2020]. 
bloody terrorist attacks in Europe. The existence of the so-called political Islam, various types of groups whose development is particularly connected with conflict between the Muslim world and the US or Western European countries, who supported the United States of America, bear the consequences of becoming involved in the war in Afghanistan and Iraq.

\section{The United Right's position towards immigrants and refugees from Muslim countries}

The Polish government of the United Right refused to take part in the European Commission's relocation scheme for refugees from Muslim countries. In their argument they referred to the very dangerous terrorist activity of political Islam, charging Islam as a religion with responsibility for the terrorist attacks.

In the course of just two years 2015-2016, around three hundred people died in Western Europe in terrorist attacks. The first attack in 2015 took place on January 7 th in Paris and was meted out against the editors of the weekly Charlie Hebdo. The attack was provoked by the publication of caricatures of Muhammad, and as a result of it twelve people were killed. Two days later - on January 9th in Paris - an attack on a kosher food hypermarket "Hyper Cacher" killed six people. Another attack took place on February 14th in Copenhagen. It was directed at the participants of a meeting devoted to the freedom of expression in art, again six people were killed. Further attacks on a much larger scale occurred on November 13th in Paris and Saint-Denis - a further one hundred and thirty-seven people were killed and three hundred and fifty-two wounded.

In the aftermath of these attacks, a state of emergency was introduced in France and the borders were temporarily closed. On March 22nd, 2016, there were two bloody attacks in Brussels - at the airport in Zaventem and at the Maelbeek metro station, near the headquarters of the EU institutions. It resulted in thirty-two people and three suicide bombers being killed, and more than three hundred and fifteen people being injured.

Another assassination attempt took place on July 14th, 2016, in Nice, France, at a fireworks display on Bastille Day, a national holiday. The terrorist driving a truck crashed into a crowd, crushing people along a twokilometre route. At least eighty-four people lost their lives immediately, 
not counting the wounded and those who later died as a result of the wounds inflicted. ${ }^{18}$ The head of the Ministry of Interior and Administration in Poland at that time, Mariusz Błaszczak, commenting on the assassination, said that "political correctness that reigns in Western Europe and 'multicultural ideology' brings its tragic results." Pierre Buhler, the French ambassador to Poland, did not agree with this diagnosis, explaining that this is not the case in France - quite the opposite to compare with other countries. Buhler said: "[...] 'multiculti' does not determine the state of affairs in France. I can't agree with the statement that it is 'multiculti' which is responsible for this evil." 19

Also in France, Normandy, on July 26th, 2016, an 84-year-old priest was murdered while celebrating the Holy Mass. And at the end of 2016, on December 22nd, a Polish truck hijacked by a Tunisian Anis Amri, after the hijacker murdered the Polish driver, mowed through a crowd at the Christmas market in Berlin. The perpetrator acted in accordance with the oath of allegiance to the "Islamic State", which speaks of "crusaders bombing Muslims every day, whose blood will be avenged." The terrorist organization therefore calls "on all Muslim brothers everywhere and let those who are in Europe kill the pig crusaders, each according to their abilities." 20

The clearly negative approach of the United Right regarding Poland's participation in solving the problem of the migration crisis was formulated before the most serious attacks in Europe. They can be found in the Sejm speech of the PiS chairman Jarosław Kaczyński from September 9th, 2015, that is, in the midst of parliamentary election campaign in Poland: "First, the number of foreigners increases rapidly, then they do not comply, they do not want to comply, they declare that they will not comply with our law, our customs, and then or at the same time impose their sensitivity and requirements in public space and in various areas of life in a very aggressive, violent way." What was supposed to confirm the above claims was a reference to the experience of Western European countries: "If anyone says that this is not true, then they should look around Europe. Let them look at Sweden. Fifty-four zones where sharia is in force and there is no state control. Fears of hanging the Swedish flag on schools, there is a custom because there is a cross on this flag. Even it turns out

18 “Zamachy terrorystyczne na świecie," http://wiadomosci.com/zamachy-terrorystyczne-na-swiecie-w-2016-roku/ [access: 1.06.2020].

19 T. Gzell: “Ambasador Francji po zamachu w Nicei: Multikulti to nie źródło zła.” Rzeczpospolita, 15.07.2016, https://www.rp.pl/Dyplomacja/160719475-AmbasadorFrancji-po-zamachu-w-Nicei-Multikulti-to-nie-zrodlo-zla.html [access: 8.07.2021].

20 J. BALICKI: “'Dzieci Abrahama'. Chrześcijaństwo - islam w dobie kryzysu migracyjnego.” “Civitas”. Studia z filozofii polityki, nr 19, Warszawa 2016, pp. 120-122. 
that Swedish students are not allowed to wear short dresses because they don't like it either." 21

In addition to Sweden, Jarosław Kaczyński also mentioned Italy, England, and Germany:

"What's going on in Italy? Churches occupied by Muslims, sometimes treated as toilets. What's going on in France? Constant disturbance, also sharia, patrols that follow, and watch over sharia. The same in London. Even in strongest Germany, such phenomena are taking place. Do you want it to appear also in Poland? That we stop being hosts in our own country?" 22

After the parliamentary elections in Poland on October 25th, 2015, the rhetoric regarding the accepting of the refugees became even more acute in connection with the issue of refugee relocation within the European Union. By using arguments regarding the bloody terrorist attacks in the capitals of various European countries the rhetoric automatically made a great impression on society.

However, they also appeared to be of a "religious" and cultural nature. The right-wing discourse regarding the demand for solidarity in receiving refugees, for example in his speech Prime Minister Beata Szydło points to the danger of losing Christian identity, Polish sovereignty or "rising from one's knees": "[...] we will not agree, Poland will not agree to any blackmail from the EU. We will not participate in the madness of the Brussels elite. We want to help people, not political elites. And I have the courage to ask the political elites in Europe the question: Europe, where are you going? Where are you going? Stand up from your knees and wake up from lethargy, otherwise you will mourn your children every day."23

There were also references directed towards Muslims. In the TVN24 programme of March 23rd, 2017, the Prime Minister Beata Szydło said that "it is impossible to separate Muslim refugees/immigrants from terrorists," and "a Muslim refugee should be viewed as a potential terrorist." 24

In turn, the Minister of the Interior and Administration Mariusz Błaszczak, speaking on TVN about the attack in Nice, stated that Poland would have found itself in this situation had it not been for the change

${ }^{21}$ J. KACZYŃSKI: "MOCNE przemówienie o muzułmańskich imigrantach,” Sejm, 16.09.2015, https://www.youtube.com/watch?v=gzxQ9cqn1yI [access: 1.06.2020].

22 Ibidem.

23 “Wystąienie sejmowe Beaty Szydło," 24.05.2017, Wirtualna Polska, https:// wp.tv/i,straszy-czy-przestrzega-beata-szydlo-o-uchodzcach,mid,2002902,cid,4051,klip. html?ticaid=61a85a, https://wp.tv/i,straszy-czy-przestrzega-beata-szydlo-o-uchodzcach, mid,2002902,cid,4051,klip.html?ticaid=61a85a [access: 24.05.2017].

24 Redakcja. Rada Programowa,

https://docplayer.pl/176005836-24-redakcja-rada-programowa.html

[access: 1.06.2020]. 
of government. "We would already have several thousand migrants from the Middle East and North Africa." The journalist hosting the programme (Konrad Piasecki) pointed out that France has 7 million Muslims and that: “[...] the minister of a country that is culturally, nationally, and religiously homogeneous should 'bite his tongue' before he advises or criticizes the secret service of a country with seven million Muslims," to which Mariusz Błaszczak replied: "This is not about nationalities, it's about culture. This is about experiences that can be seen in Western Europe. Newcomers from North Africa and the Middle East just don't integrate!"25

These types of statements by Polish politicians were noticed by world media and other institutions, one example is the following text from the report on Islamophobia prepared for the Council of Foreign Ministers Abu Dhabi, United Arab Emirates:

"Polish lawmaker Dominik Tarczynski said that he supports the burqa ban, stepping into the ongoing debate. He told the media, that Poland should not allow the construction of another mosque, until the European country can build a cathedral in Saudi Arabia, stating the relationship between the Islamic world and the West was at present unbalanced. The Polish minister Tarczynski said that Islamic face veils 'should be banned in the same way that the Christian cross is banned in Saudi Arabia. We are happy to have it once they agree that Poland can build a cathedral in Saudi Arabia. It's simple, either we are equal, we are partners, we are the same human beings - or they feel they are better than others,' the Polish minister said. Throwing his weight behind the burqa ban in a few European countries, he said that it was partly due to security reasons and partly because of storing parity between the Islamic world and the West, that the Burqa was often used as disguise by suicide bombers, child molesters, and armed robbers across the globe." 26

The survey conducted by Instytut Badań Rynkowych i Społecznych - IBRiS (Institute of Market and Social Research) in 2017, shows how deeply embedded is this fear of Islam in Poland. As much as $56.5 \%$ would prefer to lose the EU funding and 51.2\% would leave the European Union rather than accept refugees from Muslim countries.

${ }^{25}$ K. PIASECKI: "Minister spraw wewnętrznych i administracji Mariusz Błaszczak: Polska znalazłaby się w takiej sytuacji, jak Francja, gdyby nie zmiana rządu 15 lipca 2016," Piaskiem po oczach, https://www.tvn24.pl/wiadomosci-z-kraju,3/atak-w-niceimariusz-blaszczak-w-piaskiem-po-oczach,661323.html [access: 1.06.2020].

${ }^{26}$ 12th OIC Observatory Report on Islamophobia June 2018-February 2019 presented to the 46th Council of Foreign Ministers Abu Dhabi, United Arab Emirates, 1-2 March 2019, pp. 101-102, https://www.oic-oci.org/upload/islamophobia/2019/12th_ islamophobia_annual_report_2019_en.pdf [access: 1.06.2020]. 
Table 4. Answers to the survey question: "Should Poland refuse to accept refugees from Muslim countries even if it caused the following?"

\begin{tabular}{|l|c|c|c|}
\hline \multicolumn{1}{|c|}{ Consequence } & Yes & No & Difficult to say \\
\hline Loss of EU funds & $56.5 \%$ & $40.4 \%$ & $3.1 \%$ \\
\hline Leaving the European Union & $51.2 \%$ & $37.6 \%$ & $11.2 \%$ \\
\hline
\end{tabular}

Source:IBRIS. Anopinion poll conducted in June2017: "Polacy woląopuścićUEniż przyjąćuchodźców z krajów muzułmańskich," 5.07.2017, https://www.polsatnews.pl/wiadomosc/2017-07-05/sondazpolacy-wola-opuscic-unie-europejska-niz-przyjac-uchodzcow-z-krajow-muzulmanskich/.

On the other hand, the social mood is hardly surprising if one takes into account the fact that all government media has become the media of one party and all right-wing media, including Radio Maryja belonging to the consortium of Father Rydzyk, create an extremely biased picture against followers of Islam. The report on the negative image of Muslims in the Polish press in 2015-2016, enumerates eleven most frequent metaphors used to convey the dangers of immigrants from Muslim countries trying to get to Europe, namely the metaphors of (1) wave, (2) invasion, (3) war; (4) terrorism; (5) "sexual jihad"; (6) "social jihad"; (7) the socalled ideology of multiculturalism; (8) "jihad hotbed"; (9) a clash of civilizations; (10) European suicide; (11) the attack on Poland's sovereignty. ${ }^{27}$

It seems that an accurate summary of the right-wing discourse conducted in our country may be found in Barbara Pasamonik's introduction to the book she co-edited: " 'Malowanie strasznego diabła' - metamorfoza obrazu uchodźcy w Polsce" ("Painting the boogeyman" - a metamorphosis of the image of a refugee in Poland):

The migration crisis and the accompanying media (moral) panic dramatically changed the image of refugees among Poles and, thus, Poles' attitude to refugees. In the most recent, seventh edition of the European Social Survey from 2015, Polish respondents were still among the leading European countries declaring openness to refugees. The election campaign before the parliamentary elections on October 25th, 2015 and the terrorist attacks in Western Europe completely changed the image of refugees, especially those from the Middle East and Africa. [...] at the end of 2017, in Poland, despite the absence of refugees from areas of armed conflict we are at the forefront of societies declaring resentment towards refugees. The latter have ceased to arouse compassion - above all they arouse a sense of jeopardy. According to respondents, Poland's social, cultural,

27 Ł. Bertram, A. Puchejda, K.Wigura: Negatywny obraz muzutmanów $w$ polskiej prasie. Analiza wybranych przykładów z lat 2015-2016. Raport Obserwatorium Debaty Publicznej „Kultury Liberalnej”, Warszawa, styczeń 2017. 
and economic security is at risk - we are afraid of terrorism, foreign religion, and culture, as well as competition on the labour market and social benefits. Refugees who are both Arab/Middle Eastern and Muslim are seen as the most foreign and thus serve the Polish national identity as a negative point of reference. Old Islamophobia is fueling a new media panic around refugees. ${ }^{28}$

\section{The confrontation of the position of the United Right in Poland and the position of the Catholic Church towards Islam}

As mentioned in the Introduction of the present article, Monika Bobako in her work: Islamofobia jako technologia wtadzy. Studium z antropologii politycznej (Islamophobia as a technology of power. A study in political anthropology) distinguished two types of Islamophobia. The first is termed "progressive Islamophobia" while the other "conservative Islamophobia".

"The former uses the image of 'Europe' synonymous with secular modernity (as well as key ideals of individual autonomy and freedom), and its opposite is the 'Islamic world' understood as the domain of nonmodern or anti-modern values, completely determined by religious tradition. [...] On the one side of this division there is a liberal civilization of progress founded on the criticism of religious authority, on the other - the conservative world of backwardness and irrationalism. In turn, "conservative Islamophobia", which is a kind of anti-Muslim xenophobia expressing the fear of Islam from religious positions emphasizing the Christian nature of Europe. In this approach, as the author writes, the main axis of antagonism between Islam and Europe is determined by competition between two religious systems. This antagonism is closely related not only to the issue of balance of power (or lack thereof) between the Muslim world and the Christian world, but also to the theological dispute over the 'legitimacy' of claims to the 'truth' of both competing religions." 29

${ }^{28}$ B. PASAMONIK: “'Malowanie strasznego diabła’ - metamorfoza obrazu uchodźcy w Polsce." In: Kryzys migracyjny Perspektywa społeczno-kulturowa. Eds. B. PasamoniK, U. MarkowsKa-Manista. Warszawa 2017, p. 16.

${ }^{29}$ M. Вовако: Islamofobia jako technologia władzy. Studium z antropologii politycznej. Kraków 2017, pp. 311-312. 
According to the author, the distinction between the two types of Islamophobia is blurred. On the one hand, the proponents of "progressive Islamophobia" often emphasizes the Christian roots of European modernity and claim that the specificity of Christianity as a religion guided the unique development of "European civilization." According to this view, Christianity - as opposed to Islam - from the very beginning contained the seeds of modernity and secularization. An example to support this claim is the issue of the separation of the Church and state in Christianity (by giving the emperor what belongs to the emperor and giving God what belongs to God). "Conservative Islamophobia," also refers to "secular" arguments justifying the supremacy of Europe, stressing, for example, that its unique manifestation is civil rights or respect for human dignity. ${ }^{30}$

When trying to assess the fear of Islam in Poland, one should start by looking into the number of people who worship this religion in Poland. According to sources from Pew Research Center from 2010, Poland had about 30 thousand Muslims, which was less than $0.1 \%$ of the population of the whole country. They were mostly well-assimilated Tatars who, according to current observation and media coverage, do not differ significantly from other Poles in their approach to accepting refugees from Muslim countries. One of the arguments for such a statement is the fact that they do not protest against Islamophobia in Poland or vote for accepting their fellow believers from the Middle East. On the contrary, Selima Chazbijewicz, a member of the Tatar Muslim community, professor at the University of Warmia and Mazury in Olsztyn, before taking over the function of the Polish ambassador in Kazakhstan, wrote a poem about the leader of the United Right, the PiS chairman Jarosław Kaczyński:

Like the victorious Brave, you strengthen our state,

You who resurrect Polish dignity from scratch,

As the eagle soars over the rock and always,

You are right, You hurry to help. [...].

About Jarosław the Great, lord of the souls of Poles, who will lead our nation out of defeat, [...]

And you will revive Warsaw and Krakow again. [...]. ${ }^{31}$

Enes Bayrakli and Farid Hafez, authors of the report on Islamophobia in Europe, in their summary write that in Poland there is no nominal right-wing political party, but a conservative party in power, which nevertheless allows an unambiguous negative image of Islam to be spread in

${ }^{30}$ Ibidem.

31 S. Chazbijewicz: “Oda dla Jarosława Kaczyńskiego.” Rzeczpospolita, 14.09.2016, https://www.rp.pl/Polityka/309149939-Olsztynski-dzialacz-PiS-napisal-ode-doJaroslawa-Kaczynskiego.html [access: 1.06.2020]. 
state institutions. State-funded media outlets seem to carefully select their guests, who spread a stereotypical portrayal of Muslims as "violent," "terrorists," "Jihadists," "sexists," "rapists," "uncivilized," "double-faced," and in general "a threat" to European and Christian values. ${ }^{32}$

If the year 2015, when parliamentary elections were held in the shadow of the migration crisis, was marked by a significant intensification of anti-Muslim views in public discussions, then in 2016 a further developing of Islamophobic attitudes in Poland, the media, education, and other spheres of life could be observed.

The statements of right-wing politicians, the constant depiction of refugees in connection with terrorist attacks as an extremely real danger, may have had an impact on the fact that Polish society, contrary to the attitude and teachings of Pope Francis, presents mostly negative approach toward people seeking refuge in Europe.

Sławomir Łoziński notes that since May 2015 there has been a significant decline in the acceptance of refugees by Polish society. This was not prevented by the visit of Pope Francis to Poland in August 2016 and the submission by the Polish Episcopal Conference of the initiative of an organization with the participation of Caritas, the so-called humanitarian corridors. He adds that: "[...] Despite the initial interest of the Polish government in this programme, a decision to introduce it was not made. Perhaps it was influenced by the results of the public opinion poll from June 2017 , in which only every third respondent $(33 \%)$ supported this form of assistance to refugees, and nearly two-thirds $(61 \%)$ opposed it $(6 \%$ did not express an opinion)." 33

In Islamophobia in Poland: National Report 2016, prepared by Konrad Pędziwiatr, which is a part of the already mentioned European report, we may read that there is an overestimation by the respondents of the size of the Muslim population in Poland, citing as much as 7\% where in reality there is only $0.1 \%(30,000)$. This means that Polish society believes that there are more than 2 million Muslims in the country. The overestimation of the size of the Muslim community by the inhabitants of Poland is directly related to the perception of Islam as a threat. ${ }^{34}$

32 E. Bayrakli, F. Hafez: "The State of Islamophobia in Europe," https://www. islamophobiaeurope.com/executive-summary/2017-2/ [access: 1.06.2020].

${ }^{33}$ S. Łodziński: "Uchodźcy jako 'Społeczność Podejrzana' . Polska opinia publiczna wobec udzielania pomocy uchodźcom w okresie maj 2015 - maj 2017.” In: Uchodźcy $w$ Polsce. Sytuacja prawna, skala napływu i integracja $w$ społeczeństwie polskim oraz rekomendacje. Eds. A. Górny, H. GrzymaŁa-MoszczyńsKa, W. Klaus, S. ŁodZińsKi. KrakówWarszawa 2017, pp. 82-83.

${ }^{34}$ K. PęDziwiatr: “Islamophobia in Poland: National Report 2016.” In: European Islamophobia Report 2016. Eds. E. BAYRAKLI, F.HAFEZ. Istanbul 2017, p. 414. 
As many comparative studies have shown, Poles who have very limited contact with Muslims are one of the European nations who are most afraid of accepting immigrants and refugees from Muslim countries. Father Maciej Zięba in an article entitled "Haniebna rana" (A shameful wound) expressed his opinion that this attitude to the refugee case eludes the criterion of rationality. "Generalized and abstract categories take the place of specific, unfortunate people today. These people are automatically identified with economic immigrants or terrorists. Polish society's refusal to accept refugees, among whom are women and children in need of specialist medical care, indicated by Polish aid organizations, justifies its claim that women and children are also often involved in acts of terror. The doubt as to whether a really small group can threaten Christian Western civilization is refuted by the argument that they would bring large families." 35

In addition, Father Maciej Zięba notes that: the attitude towards refugee matters ignores the teaching of the Church and the Gospel. "Jesus' entire teaching is filled with concern for those humiliated and rejected - women, children, Samaritans, paupers and the sick with lepers at the forefront." According to him, the discourse in Poland regarding the reception of refugees ideologized the faith, trying to bend the teaching of the Gospel to their belief, consequently ignoring the voice of the Polish episcopate and individual bishops, and the teaching of popes, like John Paul II and Francis. ${ }^{36}$

In July 2018 in Stockholm at the congress of National Directors of Pastoral Care of Migrants in Europe, it was stated that church centres for immigrants have a problem with Poles working there who took with them the country's negative attitude towards people of other religions and cultures. In this context, one of the Swedish hosts of the meeting addressed a request to the Church in Poland to take action on the evangelical education of society and priests going to work abroad in the sphere of openness to people from other religions and cultures.

The contemporary Teaching of the Catholic Church regarding Islam is specified among others in Declaration on the Relation of the Church to Non-Christian Religions, Nostra Aetate, proclaimed by Pope Paul VI:

The Church regards with esteem also the Muslims. They adore the one God, living and subsisting in Himself; merciful and all-powerful, the Creator of heaven and earth, (5) who has spoken to men; they take pains to submit wholeheartedly to even His inscrutable decrees, just as Abraham,

35 M. ZIĘBA: "Haniebna rana.” Rzeczpospolita, https://www.rp.pl/ Publicystyka/301149961-O-Maciej-Zieba-Haniebna-rana.html [access: 8.07.2021].

${ }^{36}$ Ibidem. 
with whom the faith of Islam takes pleasure in linking itself, submitted to God. Though they do not acknowledge Jesus as God, they revere Him as a prophet. They also honor Mary, His virgin Mother; at times they even call on her with devotion. In addition, they await the day of judgment when God will render their deserts to all those who have been raised up from the dead. Finally, they value the moral life and worship God especially through prayer, almsgiving and fasting. [...] Since in the course of centuries not a few quarrels and hostilities have arisen between Christians and Muslims, this sacred synod urges all to forget the past and to work sincerely for mutual understanding and to preserve as well as to promote together for the benefit of all mankind social justice and moral welfare, as well as peace and freedom. ${ }^{37}$

Successive popes, John Paul II, Benedict XVI and Francis focused much attention on building good relations between these religions. For example, the current pontiff, during a visit to Turkey in 2014, visited the Sultan Ahmed Mosque and met with the Grand Mufti of Istanbul Rahmi, prayed with him, facing Mecca. On Holy Thursday 2016, the Pope made a symbolic gesture, washing the feet of refugee representatives, and on April 16th, being on the Greek island of Lesbos, he took three Muslim families back with him to Rome (a total of twelve people). They joined several families from Syria, who have been living in the Vatican for some time. During the midnight Mass on December 24th, 2016, Pope Francis also referred to the tragedy of the people in Aleppo and the situation of refugees from Syria, as well as the situation of children in underground shelters or "at the bottom of a boat overloaded with migrants."

Human fraternity for world Peace and living Together was signed by Pope Francis and Grand Imam of Al-Azhar in Abu Dhabi in February 2019. It stressed the following points: Terrorism is deplorable and threatens the security of people, be they in the East or the West, the North or the South, and disseminates panic, terror and pessimism, but this is not due to religion, even when terrorists instrumentalise it; good relations between East and West are indisputably necessary for both. ${ }^{38}$

37 Declaration on the Relation of the Church to Non-Christian Religions, Nostra Aetate, Proclaimed by the Pope Paul VI on October 28, 1965, no. 3, http://www.vatican. va/archive/hist_councils/ii_vatican_council/documents/vat-ii_decl_19651028_nostraaetate_en.html [access: 1.06.2020].

${ }^{38}$ Human fraternity for world Peace and living Together, signed by Pope Francis and Grand Imam of Al-Azhar, Abu Dhabi, 4.02.2019, https://zenit.org/articles/abu-dhabipope-francis-brings-appeal-for-peace-dialogue-religious-freedom [access: 1.06.2020]. 


\section{Conclusions}

The purpose of this article was to seek the answer to the questions: Why is the fear of immigrants from Muslim countries in Poland the highest in Europe and does not decrease with the passage of time? Why is the Polish society so different from other societies in this matter when they had virtually no negative experiences with Muslim emigrants? How can one explain the contradiction between the declaration of belonging to the Catholic Church by the majority of Polish society and the completely different attitude and teaching of the last popes and especially Pope Francis, as well as the teaching expressed in the documents of the Second Vatican Council.

It seems that in order to approach the answers to the above questions, political factors need to be taken into account first. There is no doubt that we are dealing here with the deliberate use of the activities of political Islam to convince society that it is the real Islam.

Political literature on the analyzed issue both in Poland and abroad indicates its connection with the phenomenon of using fear of Islam in politics, referred to as the "new populism." This phenomenon appeared in 2015 in Hungary, contributing to Victor Orban's Fidesz party winning the second term and staying in power. It is also a reference point in the other countries of Central and Eastern Europe. The referred publication of a Polish author and researcher Monika Bobako indicates that the same mechanism was used in Poland.

Some researches show that there is a significant difference between East and West Germany in the approach to Muslims. One can attempt to explain it by the fact that Germans living in the East do not have as many contacts with Muslims as Germans living in the West. Unfortunately, the reason for it is possibly also linked to the effects of the division of Europe into East and West, after the Second World War, the ramifications of which are still visible for all countries involved.

However, the question remains: Why in Poland, regarded as an majorily Catholic country by the world, even the Pope's teaching is not able to change the society's attitude towards receiving refugees, especially from Muslim countries?

Some priests supporters of the United Right in a discussion on the subject claim: "I do not have to listen to Pope Francis in these matters. The Pope is infallible only in dogmatic matters." This may mean that the field of influence of the Church is also limited, at this time.

To finish, let us consider a short statement of Cardinal Jean-Louis Tauran, who was the chairman of the Pontifical Council for Interreligious 
Dialogue, addressing all people afraid of Islam. He states that it is necessary to overcome prejudices and fears in relations between Christians and Muslims. The dialogue itself makes it possible to overcome fear because it facilitates the discovery of the other and leads to genuine encounter, and this very encounter is just what interreligious dialogue is talking about. This is because two religions do not meet, only the people professing them.

The quoted cardinal emphasized the need to make an effort on both sides to learn about the religious traditions of the other, to recognize what divides us and what brings us together and cooperate for the common good, which is not an easy task. When there is mutual trust, both parties will be able to freely explore what divides us and what unites us. In some ways Christians and Muslims are very different, in our approach to the Holy Scriptures, concept of revelation, founders of religion, Jesus and Muhammad, the Holy Trinity, etc., "but we worship the same God, the sanctity of life, the conviction that we must pass moral values on to young people, the value of the family for emotional and the moral growth of children and the importance of religion in education." 39

\section{Bibliography}

Balicki J.: “'Dzieci Abrahama’. Chrześcijaństwo - islam w dobie kryzysu migracyjnego." “Civitas”. Studia z filozofii polityki, nr 19, Warszawa 2016, pp. 111-137.

BaliCKI J.: "Przesłanki demograficzne islamofobii w Zachodniej Europie. Analiza krytyczna." Roczniki Nauk Społecznych, KUL 6 (2014), no. 3, pp. 11-30.

BALICKI J.: "Zjednoczona prawica w Polsce wobec wyzwań kryzysu migracyjnego w Europie. Perspektywa politologiczno-etyczna." Wschodni Rocznik Humanistyczny 16 (2019), no 4, pp. 63-83.

Bayrakli E., Hafez F.: “The State of Islamophobia In Europe," http://www. islamophobiaeurope.com/executive-summary/2017-2/ [access: 1.06.2020].

Вовако M.: Islamofobia jako technologia wtadzy. Studium z antropologii politycznej. Kraków 2017.

Duderija A., Rane H.: Islam and Muslims in the West. Major Issues and Debates. Cham, Switzerland 2019.

"From Antisemitism to anti-Muslim Racism. Faith Matters 2017," https://www. faith-matters.org/2017/12/08/changing-face-hate-poland-antisemitism-antimuslim-hatred/.

39 J.-L. TAuran: “We Shouldn't Fear Islam.” Zenit, 18.02.2010, https://zenit.org/ articles/cardinal-tauran-we-shouldn-t-fear-islam/ [access: 1.06.2020]. 
“Germans support democracy, but are concerned about Islam." Die Welt, 11.07.2019, https://www.dw.com/en/germans-support-democracy-but-areconcerned-about-islam/a-49549541 [access: 1.06.2020].

Górny A., GrzymaŁa-Moszczyńska H., Klaus W., Łodziński SŁ: Uchodźcy $w$ Polsce. Sytuacja prawna, skala napływu i integracja $w$ społeczeństwie polskim oraz rekomendacje. Kraków—Warszawa 2017.

Kaemingk M.: Christian Hospitality and Muslim Immigration in an Age of Fear. Grand Rapids, MI 2018.

LENDAVAI P.: Orbán. Europe's New Strongman. London 2017.

Modood T.: Multicultural Politics. Racism, Ethnicity and Muslims in Britain. Bod$\min 2005$.

Negatywny obraz muzułmanów w polskiej prasie. Analiza wybranych przyktadów z lat 2015-2016. Raport Obserwatorium Debaty Publicznej „Kultury Liberalnej", Warszawa, styczeń 2017.

OIC Observatory Report on Islamophobia June 2018-February 2019 presented to the 46th Council of Foreign Ministers Abu Dhabi, United Arab Emirates, 1-2 March 2019, https://www.oic-oci.org/upload/islamophobia/2019/12th_ islamosphobia_annual_report_2019_en.pdf [access: 1.06.2020].

PęDZiwiatr K.: "Islamophobia in Poland: National Report 2016." In: European Islamophobia Report 2016. Eds. E. BAYRAKLI, F.HAFEz. Istanbul 2017.

Pickel G., Öztürk C.: "Islamophobia Without Muslims? The 'Contact Hypothesis' as an Explanation for Anti-Muslim Attitudes - Eastern European Societies in a Comparative Perspective." Journal of Nationalism, Memory \& Language Politics 12 (2018).

Pipes D.: Poland's Muslim ban. Washington Times, 1.07.2018, https://www. washingtontimes.com/news/2018/jul/1/how-poland-responds-to-westerneuropes-illegal-mig/[access: 1.06.2020].

Raport Obserwatorium Debaty Publicznej „Kultury Liberalnej”. Negatywny obraz muzutmanów w polskiej prasie. Analiza wybranych przyktadów z lat 2015-2016, Biuro Rzecznika Praw Obywatelskich, Warszawa, styczeń 2017, https://www.rpo.gov.pl/sites/default/files/Raport_Negatywny_obraz_ muzulmanow_w_polskiej_prasie_Analiza_wybranych_przykladow_z_ lat_2015_2016.pdf [access: 1.06.2020].

Rose St: "From antisemitism to anti-Muslim racism: The evolving face of the far-right in Poland," Faith Matters, 2017, London 2017, https://www.faithmatters.org/2017/12/08/changing-face-hate-poland-antisemitism-antimuslim-hatred/[access: 1.06.2020].

Tauran J.-L.: “We Shouldn’t Fear Islam.” Zenit 18.02.2010.

Tenth OIC Observatory Report on Islamophobia, October 2016-May 2017, presented to the 44th Council of foreign ministers Abidjan, Republic of Cote d'Ivoire 10-11 July 2017.

Trines St.: “Europe. Lessons From Germany's Refugee Crisis: Integration, Costs, and Benefits." World Education News \& Reviews, 2.05.2017, https://wenr. wes.org/2017/05/lessons-germanys-refugee-crisis-integration-costs-benefits [access: 1.06.2020]. 
JaNUSZ BALICKI

\title{
L'islamofobia in Polonia nel contesto della crisi migratoria in Europa
}

\begin{abstract}
I sondaggi di opinione pubblica internazionali mostrano che uno dei più alti livelli di paura dell'Islam in Europa è apparso in Polonia durante la crisi migratoria nel 2015. Ciò è avvenuto nonostante nell'Unione Europea la Polonia sia uno dei paesi con la più bassa percentuale di musulmani rispetto alla popolazione del paese; si tratta infatti di circa 30 mila di Musulmani rispetto a 38,5 milioni di abitanti $(0,1 \%)$. Una tale reazione degli abitanti del Paese sarebbe qualificabile come islamofobia, termine spesso utilizzato nella letteratura delle scienze sociali e politiche. Lo scopo di questo articolo è cercare di spiegare le ragioni di un così alto livello di paura degli immigrati dai paesi musulmani in Polonia e dell'atteggiamento negativo nei confronti dell'Islam in quanto religione. Allo stesso tempo, si tiene conto del fatto che ciò è contrario all'insegnamento della Chiesa cattolica, con cui la società polacca si identifica in gran parte. L'articolo si compone di tre parti. La prima parte presenta la risposta degli Stati membri dell'UE alla crisi migratoria in Europa. Nella seconda parte si analizza la posizione della coalizione politica, la Destra Unita, in Polonia nei confronti degli immigrati e dei rifugiati dai paesi musulmani. La terza parte, invece, confronta la posizione della Destra Unita sull'Islam con l'insegnamento della Chiesa cattolica.
\end{abstract}

Parole chiave: islamofobia, crisi migratoria, rifugiati, populismo, politica migratoria, UE, solidarietà

JANUSZ BALICKI

\section{L'islamophobie en Pologne dans le contexte de la crise migratoire en Europe}

Résumé

Les sondages d'opinion publique internationaux montrent que l'un des niveaux les plus élevés de peur de l'islam en Europe est apparu en Pologne lors de la crise migratoire en 2015. Cela s'est produit malgré le fait que la Pologne est l'un des pays avec le plus faible pourcentage de musulmans dans l'Union européenne par rapport à la population du pays ; environ 30 mille de Musulmans par rapport à 38,5 millions d'habitants $(0,1 \%)$. Cette condition peut donc être décrite par le terme d'islamophobie, qui est souvent utilisé dans la littérature des sciences sociales et politiques. Le but de cet article est d'essayer d'expliquer les raisons d'un tel niveau de peur des immigrés des pays musulmans en Pologne et l'attitude négative envers l'islam en tant que religion. En même temps, cette attitude est contraire à l'enseignement de l'Église catholique, avec laquelle la société polonaise s'identifie largement. L'article se compose de trois parties. La première partie présente la réponse des États membres de l'UE à la crise migratoire en Europe. La deuxième partie analyse la position de la coalition politique, la Droite Unie, en Pologne 
vis-à-vis des immigrés et des réfugiés des pays musulmans. La troisième partie, en revanche, confronte la position de la Droite Unie sur l'islam à l'enseignement de l'Église catholique.

Mots clés: islamophobie, crise migratoire, réfugiés, populisme, politique migratoire, UE, solidarité 